\title{
Pedagogy in Architectural Design Studio and Sustainable Architecture in Nigeria
}

\author{
A. 0. Olotuah ${ }^{1}$ \\ A. A. Taiwo² \\ 0. 0. ljatuyi ${ }^{3}$ \\ 1, 2, 3 Department of Architecture, Federal University of Technology, Akure 340001, Nigeria \\ aoolotuah@futa.edu.ng; aataiwo@futa.edu.ng. ooijatuyi@futa.edu.ng
}

Doi:10.5901/jesr.2016.v6n2p157

\begin{abstract}
This paper discusses teaching and learning in the design studio in architectural education in Nigeria, and the roles they play in promoting sustainable environment. Architectural design studio is one of the seven modules of study in architecture schools in Nigeria as stipulated by the National Universities Commission. A case study of the Federal University of Technology Akure Nigeria and Covenant University Ota Nigeria is presented. The paper asserts that the design studio is central to architectural programme and the practice of architecture. It emphasises the need for an improvement in the architecture curriculum particularly the design studio to inculcate further sustainability studies. This is in view of its key integrative role in the attainment of a humane and sustainable human environment.
\end{abstract}

Keywords: architecture, built environment, curriculum, design studio, education.

\section{Introduction}

Pedagogy is the art and science of teaching. The term generally refers to strategies of instruction, or a style of instruction. Pedagogy is also occasionally referred to as the correct use of instructive strategies. Teaching encompasses the transfer of a body of knowledge to students, the evaluation of the performance of the students as well as socialization. Teaching is however one of the three roles expected of the teacher, the other two being administration and his guidance and counselling role (Ezewu, 1983). Learning and its behavioural responses are considered fundamental to man's survival since his continued existence depends on how well he adjusts and adapts to his environment. There is more to education than merely the transmission of knowledge. Learning means, in addition to the acquisition of academic knowledge and skills, the processes involved in the all-round and full development of the student both as an individual and as a member of society. The teacher's role should aim at inculcating the development of character and thus promote the physical, aesthetic, social, spiritual, intellectual and moral development of the student. This is socialization, which is the process by which an individual acquires the societal morals and values of the society. It is geared towards the preparation of the students for participation in the life of the society.

Good teaching requires a fine blend of subject knowledge, teaching methodology, psychology of learning and of learners, and an especially relevant creative attitudinal orientation on the part of the teacher. This is trenchant teaching, which is the instruction that leads to effective learning. It means thorough and lasting acquisition of the knowledge, skills, and values the teacher or the institution, has set out to impart (Felder \& Brent 1999). Trenchant teaching is the activity which brings about the most productive and beneficial learning experience for students and promotes their development as learners. The teacher should know his subject and his object (students) and the right philosophies of education.

The design studio is the work space and the primary course of study of architecture students. The greater part of the architecture programme centres on the design studio and it thus has a pre-eminent position. It is the hub of the architectural programme. The acquisition of skills by architecture students is assessed in the design studio. As it is the major concern of the architecture programme the design studio is often assigned about $50 \%$ (fifty percent) of course units required for graduation. The entire architectural programme thus culminates in the design studio where students develop the skills for effectively shaping, ordering and articulating the built environment. Learning in the design studio is therefore of crucial importance in the study of architecture and it is contingent upon the teaching methodology and curriculum of the school. 
The curricula of the architectural design studio of two schools of architecture in Nigeria, namely the Federal University of Technology Akure (a Federal University) and Covenant University Ota (a private university) are examined in this paper to show their coverage, direction and emphasis. The pedagogical methods of teaching, learning and evaluation in the design studio of both schools are discussed. The paper further discusses the contents of the course curricula with regard to sustainable architecture which is a general term that describes environmentally-conscious design techniques.

\section{Teaching Methodology}

Lecturers are supposed to possess competence in their various fields and the skill and experience necessary to impact knowledge to students. The emergence of new technology has resulted in radical transformation in teaching methods over the years (DeLappe 2005). The teaching method in institutions of higher learning is lecturing. This involves a threefold task of giving information predominantly by oral methods, generating understanding and creating interest in learning. Without interest attention is lost, and so there can be little understanding. Without information, there is nothing to be understood (Brown 1978).

Lecturing is as effective as other methods of teaching for imparting ideas and information. Lecturing is probably not, on balance, as effective as small-group teaching for attitudes (Bligh 1972, Bligh \& Piper 1975, Costing 1972, McCleish 1976). The most important thing in lectures is "not what the lecturer says or writes but what the students have learnt and what encourages them to learn more"(Brown, 1978). The amount of knowledge assimilated by learners depends on the amount to which they are exposed.

\subsection{Various formats in lecturing}

Below are various formats which can be adapted to suit particular situations, disciplines and sizes of classes in lecturing (Brown 1978; Brown and Atkins 1988; Davis 1993; Frederick 1986; Penner 1984).

i. Construction/Creative method. The method emphasizes the practical aspect of learning. The students construct things using different materials like cardboard, wood or clay. They may also do construction drawings such as plans, sections, elevations and details. The method also tests the creative ability of the student. It includes freehand drawing, sculpture, and painting. It is particularly appropriate for the design studio in architectural education.

ii. Problem solving: This method encourages students to think for themselves. It could begin with the lecturer posing a question, quizzes, puzzles or paradox.

iii. The case study method: This follows a realistic situation step-by-step to illustrate a general principle or problem-solving strategy. Depending on the level of the students, either the lecturer takes the lead or the students themselves generate the questions and principles.

iv. Inquiry Method: The lecturer involves the students in activities of collection, assimilation analysis and presentation of data. It comprises surveys, interviews, questionnaire administration, and field trips.

\section{The Design Studio}

The studio refers to the space where the student or the professional architect produces his or her drawings. However, the meaning of the design studio in architecture is not limited to the space; the design studio also describes the architectural design course which the architecture student takes to earn a degree. It is the nucleus of architectural programme. In many Universities it carries about $50 \%$ of the credit hours and units required to earn a first degree. Architectural education centres round the design studio for sustainable reordering and reshaping of the built environment. From the curriculum of architectural education, students are taught to grasp the basics of design for effective and sustainable application in real life. A curriculum is a set of planned programme of activities designed to offer learning experiences to students under the guidance of a school. It is as an integrated collection of courses and activities developed in response to social needs and related to the needs of the culture that supports the school.

Architectural design studio is one of the seven modules of study in architecture schools in Nigeria as stipulated by the National Universities Commission. The other six are:

I. $\quad$ Arts and Drawing

II. Historical and Theoretical Studies 
III. Building Systems and Technology

IV. Humanities and Social Studies

V. Environmental Control System and

VI. Physical Sciences.

\section{Research Methodology}

The research examined the design studio in two schools of architecture in Nigeria. The objectives of the research were to:

1. investigate the coverage, direction and emphasis of the architectural design course particularly with reference to sustainable architecture in the schools selected as case studies;

2. examine the pedagogical methods adopted for teaching and learning in the design studio of the schools investigated; and

3. examine the methods of assessment and evaluation of the architectural design course in the schools.

Purposive sampling was used to select two schools of architecture from southwest Nigeria as case studies for the research. The two schools are the Federal University of Technology Akure Nigeria and Covenant University Ota Nigeria. Both schools have well established departments of architecture that are accredited by the National Universities Commission, and the professional body regulating architectural education in Nigeria, which is the Architects Registration Council of Nigeria (ARCON).

Primary data for the study were obtained from participant observation and interviews conducted in the two schools. Members of staff of the departments were interviewed on the structure, organisation and philosophy of the schools. The interviews examined pedagogical issues on the study of architectural design course. In particular, teaching methodology and learning in the design studio, and assessment and evaluation of students' creative outputs were examined in both schools. Secondary data were obtained from university publications (students' calendar, handbooks, course synopsis) obtained from both schools.

\subsection{Curriculum of the architectural design course at The Federal University of Technology Akure Nigeria}

At the undergraduate degree level the design studio is taught in 4 (four) academic sessions (2 ${ }^{\text {nd }}$ year to $5^{\text {th }}$ year) at the Federal University of Technology Akure Nigeria. It is a course that runs through both semesters of the academic session. Course mentors are appointed to teach and guide the students in the course. Appropriate methods of teaching (Construction/Creative method, Problem solving method, Inquiry Method and Case Study method) are used for mentoring the students in the various classes. Below are the course synopses for the various courses (Federal University of Technology Akure, Nigeria, 2005, 2013).

\subsubsection{ARC 201 A and B (Architectural Design I \& II)}

This course totals 8 units and marks the inception of the students' design activities in the University, and the principal aim of the course is to enable the students grasp the effective use of forms and elements.

\subsubsection{ARC $301 \mathrm{~A}$ and $\mathrm{B}$ (Architectural Design III \& IV)}

Architectural design III and IV is a ten-unit course and comprises major and minor projects. The major project involves the design of industrial buildings for the part $\mathrm{A}$, while the students are made to effectively handle institutional and complex design projects for part B. In addition, housing project with specific study of rural development is done under the minor project.

\subsubsection{ARC 401 (Architectural Design V)}

Architectural design V (ARC 401) is Urban Renewal Scheme and it is geared towards exposing the students to contemporary urban problems with the aim of finding solutions to them. Urban Renewal Scheme places strong emphasis on redevelopment, renovation, conservation and presentation. Within this scheme, a minor scheme such as the design of shopping centre, primary school, health centre, post office will be carried out by the students. 


\subsubsection{ARC 501 (Advanced Design Studio)}

Arc 501 is a mass housing scheme of twelve units that consists of both major and minor projects. For the major project, a typical housing scheme for a fairly large population is worked upon based on different housing concepts. The minor project is a communal facility in the housing scheme.

\subsection{Curriculum of the architectural design course at Covenant University Ota Nigeria}

The curriculum is run similarly to the Federal University of Technology Akure, The courses however run on semester basis. Mentors are appointed by the department and they guide and teach the students using appropriate methodology (Construction/Creative method, Problem solving method, Inquiry Method and Case Study method). Below are the course synopses (Covenant University Ota, Nigeria, 2010).

\subsubsection{ARC 211 Architectural Design I (4 Credit Units)}

This is a studio course using abstract designs to develop creative thinking, analytical skills and aesthetic sensitivity in architectural design. Architectural forms, principles of proportion, rhythm, harmony, contrast, texture, mass, volume colour, tectonics and modelling in architecture. Physical, morphology and attributes of space, ordering of spaces, interior and furniture design.

\subsubsection{ARC 221 Architectural Design II (4 Credit Units)}

Development over the ARC 211, with exercises on small scale projects like simple residential designs, kiosks, day-care centre, village market, village health care, health centres etc. Quick approach project is introduced.

\subsubsection{ARC 311 Architectural Design III (4 Credit Units)}

The course introduces students to rural development in Nigeria. It also examines the rural town as part of development and the role of architects in the overall physical development. Some socio-economic and other demographic data will be of advantage to this development.

\subsubsection{ARC 321 Architectural Design Studio IV (4 Credit Units)}

Students are to be exposed to interdisciplinary aspects of architectural design, where constraint like site, climate, landscape, structure all get their due place and the final design decisions are the outcome of their combinations. Programmes formulation and evaluation, therefore, though still simple is comprehensive and multi-functional.

\subsubsection{ARC 411 Architectural Design V (2 Credit Units)}

Design programmes at this stage lay emphasis on the understanding of an environment in its totality, in which the context of the design in physical, cultural and economic terms is fundamental. Programmes are to concentrate on settings, building groupings and live urban design problems where surveys, problem identification, design criteria, programme formulation become integral part of the whole process.

\subsubsection{ARC 421 Architectural Design V (2 Credit Units)}

More complicated Design brief is desirable at this stage where detailed emphasis is laid on a thorough understanding of the economic and structural factors in building. Other key consideration is on the position of the services and the entire environment. Difficult terrain would be suitable to enable the student display a clear understanding of the topographic drawings. 


\subsection{A review of the design studio of both schools}

Teaching in the design studio is a function of the philosophy of the schools of architecture. In both schools of architecture (Federal University of Technology Akure and Covenant University Ota) design lecturers are referred to as design mentors as they are supposed to guide their students through their design projects and assist them in putting their design ideas and thoughts into proper shape. The emphasis therefore is not in forcing the ideas of design lecturers on students. In both universities design projects are taught as theory and projects which implies that some theory aspects are taught in the studio to provide a background for the projects and to give the students proper directions in their thought process.

A lot of emphasis is placed on creativity and functionality which derives from intuition and the imaginative power of the students. This calls for the creative method of teaching which emphasizes the practical aspect of learning while drawing on the inherent ability of students to 'see in their minds' eyes'. The design mentors require skills in architectural design as well as in transmitting ideas to students to sharpen and heighten their inherent design skills.

Problem solving, inquiry and case study methods are also employed enabling students to think for themselves and apply their intellect appropriately. Field trips are organized as part of the design programme for the semester or session to improve upon the students' learning experiences outside the design studio through firsthand contact with real life situations. The students are offered the opportunity to make overseas trips to attend international summer schools that provide an interesting mix of studio exercises, lectures given by renowned architects from leading practices, and visits to great cities with outstanding architectural masterpieces, and places with practical examples of sustainable development projects. Students from both universities have attended summer schools at Lincoln School of Architecture and Design, University of Lincoln, Lincoln United Kingdom.

The design studio is assessed through a jury system at the end of the semester in both schools. Students are required to present their projects to a group of jurors who evaluates the projects based upon set requirements. The criteria are creativity and originality, functionality, graphic communication, structural viability, and oral presentation and comportment. Submission requirements are stated in the design briefs given to the students at the outset of the design projects at the beginning of the semester or session.

Sustainability is subtly taught in both schools of architecture as issues of the environment are discussed as a part of the theory and projects in the design studios. The projects are not specifically geared towards sustainable development and there is no semester design project that is designated as such. The synopsis of the design projects does not make any reference to sustainability and therefore the design briefs given to the students at the beginning of the semester do not discuss it. Aspects of sustainable development are however taught in a few courses in both schools particularly in the Master's programme.

\section{The Design Studio and Sustainable Environment}

The design studio is the nucleus of architecture programme and practice. The entire architecture programme culminates in the design studio. The architect-educator is expected to impart the students with the skills that will enable them to be competent in architecture and its practice. Subsumed in the design studio are other modules in architectural curriculum. Essentially, the knowledge of the other modules is applied in the design studio to achieve sustainable designs. This therefore implies that the practice of architecture requires that the student gains considerable knowledge and skills to practice architecture and solving problems in the built environment.

Sustainability in the built environment involves promoting energy-efficient buildings and minimising negative impacts on the environment. Sustainable buildings are designed, built and managed in a way that makes them as environmentally-friendly as possible. Sustainability is achieved through minimizing climate change, reducing pollution and improving air quality and health, and thus creating sustainable settlements. For a building to be sustainable, it must respond to the social and economic conditions of the context within which it exists.

The housing situation in Nigeria is of utmost concern as it is generally of poor quality in both rural and urban centres (Daramola, Oluwole, Aduwo and Ogbiye, 2005; Olotuah, 1997, 2002; 2006; Olanrewaju, 2001, Adedeji \& Olotuah 2012). The inadequacy in housing experienced in the rural areas is in qualitative terms, whereas in the urban centres housing is inadequate quantitatively and qualitatively. The poor quality of most of the houses is evident in their state of repair which is consequential of use of materials of poor quality and substandard construction techniques. Concrete with excessive quantities of dust and clayey matter is used for construction in many urban and rural houses, and this has been found to be pernicious to the production of good quality concrete (Olotuah, 2015; Arum \& Olotuah, 2006). Nigeria has experienced a rapid rate of urbanisation in the last one hundred years (Mabogunje 1980; Onibokun 1985; Olotuah, 
2005; Olotuah \& Aiyetan 2006) resulting in explosive population growth in existing urban centres. This has resulted from seemingly unabated rural-urban migration on the one hand, and increases in the size of the concentration points in the urban centres on the other. This poses a daunting challenge for built environment professionals especially architects and curriculum planners.

Housing sustainability is a crucial aspect of the curriculum deserving attention in order to enhance the quality of the built environment. Housing which ensures satisfaction, well-being, and productivity of the users and is environmentfriendly is one which takes into consideration key sustainable factors. Because housing is central to quality of life and consumes large amounts of resources in its construction, maintenance and use, it contributes significantly to sustainability. Asif, Muneer, \& Kelly (2007) have shown that the building industry consumes $40 \%$ of the materials entering the global economy, and is responsible for almost half of the global green house gases.

The curriculum in architecture schools in Nigeria recognises the place of sustainability in the development of the built environment. This is apparent in a few theory courses but is absent in design studio programme. The curriculum thus requires a critical re-structuring in order to be socio-economically and physically relevant and to meet the country's pressing national needs in the sustainability of the built environment. It is also imperative for the curriculum to keep up with the global pace of sustainable development to ensure healthier living, better welfare and greater productivity of the populace.

\section{Conclusion}

The paper reviews the design studio of the Departments of Architecture of The Federal University of Technology, Akure and Covenant University Ota in Nigeria. It asserts that the design studio is central to architectural programme and the practice of architecture. The quality of the human environment is the principal concern in architecture. Thus architectural education strives to train professionals who would understand the nature of the human problem in its environmental context and possess the intellectual and aesthetic skills to create relevant and expressive design solutions. In this bid teaching and learning in design studios in architectural education would foster students' creativity and strengthen their interest, motivation and commitment to achieve and maintain sustainable human environment.

\section{References}

Adedeji Y. M. D. and Olotuah A. O. (2012) "Accessibility of Low-Income Earners to Housing Finance in Nigeria" European Scientific Journal, June edition, 8 (12) ISSN: 1857 - 7881 (Print) e - ISSN 1857- 7431, 80 - 95

Arum, C. and Olotuah, A. O. (2006): 'Making of Strong and Durable Concrete' Emirates Journal for Engineering Research (EJER), 11 (1) 25-31

Asif, M., Muneer, T. and Kelly, R. (2007) "Life cycle assessment: A case study of a dwelling home" Scotland, Building and Environment, 42,1391

Bligh, D. (1972). What is the Use of Lectures? Penguin Books Harmoundsworth

Bligh, D. E. and Piper D.W. (1975) Teaching Students, University of Exeter

Brown G. (1978): Lecturing \& Explaining; Richard Clay (The Chaucer Press) Ltd, Bungay, Suffolk

Brown G. and Atkins, M. (1988) Effective Teaching in Higher Education, London: Methuen

Costing, F (1972) "Lecturing versus other methods of teaching: a review of research" British Journal of Educational Technology, 3, 1-31

Covenant University Ota, Nigeria (2010) Curriculum for Architecture Programme

Daramola A., Oluwole A., Aduwo B. and Ogbiye S. (2005): "Public-Private Partnership and Housing delivery in Nigeria", Conference Proceedings of Africa Union of Architects Congress, Abuja, 23-28 May, 26 - 44

Davis, B. G (1993) Tools for Teaching; San Francisco: Jossey-Bass Publishers

DeLappe, J. (2005) "A Critical Teaching Strategy for the Digital Arts," http://www.uiah.fi/bookshop/isea/j/05.htm, USA

Ezewu, E. (1983) Sociology of Education, Longman Group Limited, Essex, UK

Federal University of Technology Akure, Nigeria (2005) University Calendar

Federal University of Technology Akure, Nigeria (2013) Students' Handbook, Department of Architecture 2013 - 2015

Felder, R. M. and Brent, R. (1999) "How to Improve Teaching Quality", Quality Management Journal, 6 (2), 9 - 21

Frederick P. J. (1986) "The Lively Lecture - 8 Variations" College Teaching, 34 (2), 43 - 50

Mabogunje, A.L. (1980) The Development Process: A Spatial Perspective $2^{\text {nd }}$ Ed., Unwin Hyman Ltd, London

McCleish, J. (1976) "The Lecture Method" In Gage N. L. (Ed.) The Psychology of Teaching Methods, 75th Yearbook of the National Society for the Study of Education

Olanrewaju, D.O. (2001) Urban Infrastructure A critique of Urban Renewal Process in ljora, Badia. Habitat International, 20: 517 - 530

Olotuah, A. O. (1997) "The House: Accessibility and Development - A Critical Evaluation of the Nigerian Situation" In Bayo Amole (Ed.) The House in Nigeria, Proceedings of the National Symposium, Obafemi Awolowo University lle - Ife, Nigeria, 23 - 24 July, 312 
$-317$

Olotuah, A.O. (2002) "An Appraisal of the Impact of Urban Services on Housing in Akure Metropolis" Journal of Science, Engineering and Technology, 9 (4) 4570 - 4582

Olotuah, A. O. (2005) "Sustainable Urban Housing Provision in Nigeria: A Critical Assessment of Development Options" Proceedings of the Africa Union of Architects Congress, Abuja, 23 - 28 May, 64 - 74

Olotuah, A. O. (2006): "Housing Quality in Suburban Areas (An Empirical Study of Oba-lle, Nigeria)" DIMENSI Journal of Architecture and Built Environment 34 (2) 133-137; https://doaj.org/article/43f45c9fe3334dca953a2624b31b9a08

Olotuah A.O. (2015) "Accessibility of Low-Income Earners to Public Housing in Ado-Ekiti Nigeria" Journal of Civil and Environmental Research, 7 (7) 1 - 5; http://www.iiste.org/Journals/index.php/CER/article/view/23739

Olotuah, A. O. and Aiyetan A. O. (2006): "Sustainable Low-Cost Housing Provision in Nigeria: a bottom-up, participatory approach" In Boyd, D (Ed.) Proceedings of 22 ${ }^{\text {nd }}$ Annual ARCOM Conference, 4 - 6 September, Birmingham, UK, Association of Researchers in Construction Management, 2, 633 - 639

Onibokun, A.G. (1985) "Housing Finance in Nigeria: A Critical Survey of Private and Public Sources." In Onibokun A.G. (Ed) Housing in Nigeria, Nigerian Institute of Social and Economic Research (N.I.S.E.R) Ibadan, 199 - 219

Penner, J. G. (1984) Why Many College Teachers Cannot Lecture. Springfield, Ill.: Thomas 
